\title{
Analysis of the Current Employment and Development Space of Ceramic Major Students
}

\author{
Yongmei $\mathrm{Wu}$ \\ Shandong University of Arts \\ Jinan, China 250000
}

\begin{abstract}
China" refers not only to China but also to porcelain. The brilliant ancient ceramic culture has always been the pride of the Chinese nation. Chinese ceramics have a wide range of awareness both at home and abroad, but the employment status of current ceramics majors is not satisfactory. The purpose of this dissertation is to study its specific reasons with the focus on the analysis of domestic and international developmental forms of ceramics. In the meantime, it will carry out comparative analysis between the development of the world's top ceramic brands and the teaching of ceramics in China's universities to explore the current employment and development space for ceramics.
\end{abstract}

\section{Keywords—ceramics; employment; development; space}

\section{INTRODUCTION}

The birth and development of ceramics has enriched human civilization. China has produced real porcelain in the Han Dynasty and is the first country in the world to burn porcelain, more than 1,500 years before Japan and 1600 years earlier than Europe. However, "the pottery arts of the West and Japan in the 20th century have grown by leaps and bounds. In contrast, the development of China' $\mathrm{s}$ modern pottery arts has been sluggish, and the quality of ceramics produced has gone from bad to worse. The ideas and techniques of pottery art have remained in the fray of archaizing and imitate ancient model..." In the 21 st century, China's economy and culture have entered a period of prosperous and stable development. What kind of space for ceramic art will develop in China and abroad? What will be the impact on ceramics students?

\section{THE DEVELOPMENT SPACE OF CERAMIC ARTIN CHINA}

The recognition and attention of ceramic arts in China will directly affect the employment and development of ceramics majors. Chinese ceramic art has a broader space for development in the present, and is embodied in the following aspects:

- China has a long history of ceramics and a splendid ceramic culture. The Chinese people have ceramics affection of a long history. The creation of predecessors has laid a solid foundation for the development of modern Chinese ceramic art. Porcelain-producing areas throughout the country have created ceramic products of different styles according to the characteristics of local ceramic raw materials. However, these products cannot meet the needs of different consumer groups, and still require professional research and development;

- With the popularization of higher education at the present time, the creators engaged in modern ceramic art have a high cultural standard, and in particular, the ceramics profession has been established as a separate discipline in qualified colleges and universities, cultivating ceramic talents with strong professional qualities. While learning about traditional ceramic knowledge, they have begun to use the Internet to pay attention to the development of modern ceramic art in the world. They are easy to digest and accept foreign information and are very inclusive in terms of creative ideas, which is conducive to the innovative development of ceramics.

- With the development of society, ceramics are being used as a medium to be tried and used by artists other than ceramics profession. More and more artists use clay to express modern art. Artists involved in ceramic art have grown dramatically in recent years. The Shandong University of Arts has successfully held two sessions of Cross-domain Modern Ceramic Art Exhibition of "Jie - Shang" \& an Exhibition of Chinese Contemporary Ceramic Experiments Art (see "Fig. 1").The exhibition has received extensive attention, praise and recognition from the society. These works will stimulate students' learning and creation from another perspective of art;

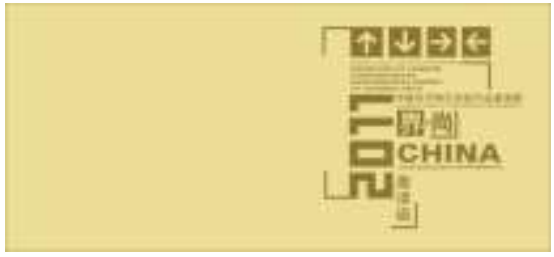

Fig. 1. Cross-domain Modern Ceramic Art Exhibition of "Jie · Shang".

- With the development of economy, the environment of contemporary ceramic art in China has been improved, and the creation of potters has been affirmed and the corresponding economic returns can be achieved. The graduates of the ceramics profession no longer become the workers in the porcelain production area, and more people choose to open 
individual ceramic art studios. The relaxed space and atmosphere help to promote the independent creation of modern ceramic artists and enrich the content and form of contemporary Chinese ceramic art.

- The vigorous support of the mass media, especially the launch of various television columns involving ceramic arts, such as "Jianbao" and "Collections" allows more people to know about and understand the traditional and modern ceramic culture, developing more audience for the modern ceramic art. Making pottery and enjoying pottery have become a fashionable and temperament leisure activity.

- Various ceramic art design competitions and contemporary Chinese ceramic art exhibitions are held under the strong promotion of universities, ceramic companies, museums, and art galleries. While promoting Chinese contemporary ceramic art and raising the level of ceramic art design, they are also promoting the social status of ceramic artists. Contemporary ceramic art is no longer considered as an edge of arts and crafts but as important as other art categories. Starting from the 9th National Art Exhibition, the ceramic art direction began to participate with Chinese paintings, oil paintings, prints, and sculptures, which greatly increased the confidence of contemporary ceramic art creators. In the 12th National Art Exhibition in 2014, ceramic art works were included as independent art categories, and a special exhibition hall was set up, so that the ceramic art can be more valued and concerned by more people.

- With the appearance of collectors and ceramic critics, collectors, museums and art galleries are all love collecting ceramic art works, making the value and significance of ceramic art creation equal to other types of artistic creation. The emergence of ceramic critics has raised the contemporary ceramic art from the theoretical height. In the affirmation and negation of contemporary ceramic art, they have been promoting the development of contemporary Chinese ceramic art and continuously improving the aesthetics of contemporary Chinese ceramic art.

- The state's support for the cultural industry and the promotion of the "Belt and Road Initiative" policies has created a larger trading platform for ceramics, an important trade product in the ancient Silk Road. It is worthwhile for ceramic art practitioners and ceramic art students to think and innovate how China's contemporary ceramic art should be presented to the "Belt and Road" partners with a new look.

\section{INTERNATIONAL CERAMICS MARKET WORTH RESEARCH AND DEVELOPMENT}

Before 1703, Chinese porcelain led the development of porcelain in the world. However, after 1790, countries in the world began to block China's porcelain exports. Two hundred years later, what is the status of Chinese ceramics in the international market? According to a recent survey, $70 \%$ of the world's daily-use porcelain is produced in China, and 2/3 of the world's people use Chinese-made porcelain. However, in any high-level department store and shopping mall in the world, there is no Chinese brand of porcelain.

\section{A. The Study of the World's Top Ceramics}

The world's top brands of daily-use porcelain are mainly distributed in Europe, such as Denmark's Lcopenhagen ceramics, the world's top 500 - France Hermes ceramics, Hungary Herend ceramics, UK Royal Doulton, UK Wedgwood ceramics for daily use, Delft in the Netherlands, and Meissen, a famous German ceramic brand. The shadow of Chinese porcelain can be seen in more or less of the products of these top ceramic companies.

Josiah Wedgwood is known as "the father of British ceramics."The Encyclopaedia of Great Britain commented on him: "The outstanding research on ceramic manufacturing, the in-depth exploration of raw materials, the rational arrangement of the labor force, and the vision and insight of the business organization have made him one of the great leaders of the industrial revolution."After the death of Josiah, his children and grandchildren inherited the ancestral cause, and always made Wedgewood a world leading ceramic brand. The Wedgwood brand has also become the symbol of the most British traditional ceramic art in the world. Wedgwood ceramics are of noble quality, delicate texture, concise style, and very artistic. Elegant and classical high-relief (are known as stenciled decals in ceramics profession) has always been the style of Wedgwood ceramic products ("Fig. 2"). As early as in the Tang dynasty, China, the mould applique kettle of Changsha Kiln was very distinctive ("Fig. 3"). However, two thousand years later, Changsha Kiln still fails to become the leading brand of ceramics in the world.

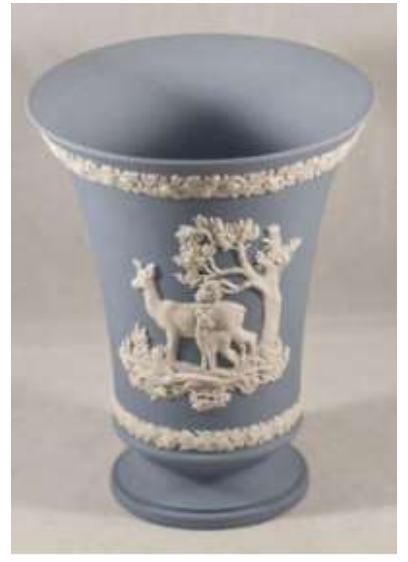

Fig. 2. Wedgwood ceramic. 


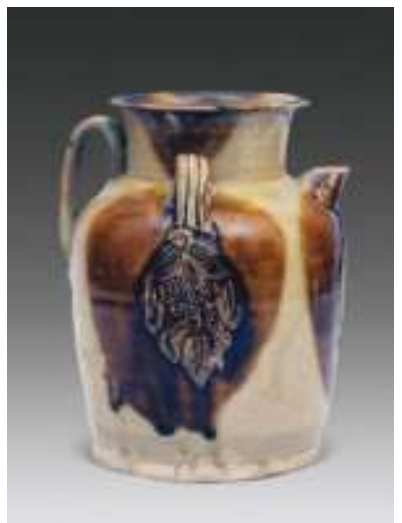

Fig. 3. The mould applique kettle of Changsha Kiln of China in the Tang dynasty .

Among the luxury goods in Germany, Porsche ranks first in the brand and the second is Meissen Porcelain. As the center of porcelain in Europe, Meissen Porcelain has been affecting the western table culture, food culture and artistic aesthetics for three hundred years. Meissen porcelain has always been the chasing object by the royal family, stars and politicians in Europe. Its price is as high as gold. Now, even a small coffee cup costs 60 Euros (more than 600 yuan). A set of Meissen Porcelain named "Arabian Nights", which is rich in characters creation is worth more than 1 million euros. As shown in Fig.4, the Meissen ceramic kettle is priced at 45,000 euros, and it is made by using a ceramic. This decoration can be seen everywhere in the small workshops of Jingdezhen sculpture and porcelain factory in China "Fig. 5", but the price of porcelain bottles with knurled decal decoration produced in sculpture and porcelain factory is less than one-thousandth of Meissen's ceramics.

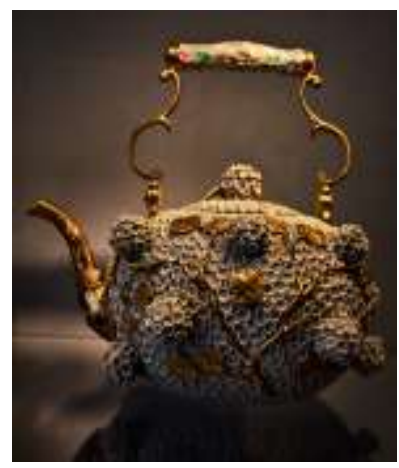

Fig. 4. Meissen Porcelain.

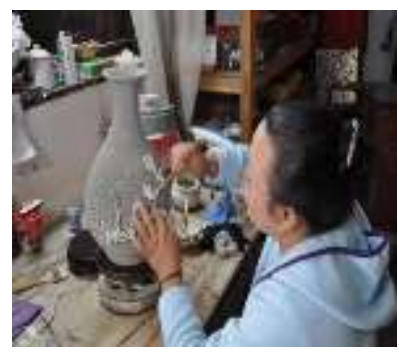

Fig. 5. The knurled decal decoration of Jingdezhen sculpture and porcelain factory in China.
Holland has a famous ceramic city - Delft, which is one of Dutch East India Co's 6 strongholds in Holland. It was at that time that Chinese porcelain was introduced into the Netherlands and developed into the famous Delft blue-andwhite porcelain in the Netherlands. The city produced blueand-white porcelain ware [2] with a history of more than 700 years, and was awarded the title of "Royal" by the Dutch royal family in 1919. Its refined blue-and-white ceramics are well known and the products are sold at home and abroad ("Fig. 6").From the blue and white porcelain of Delft, the shadow of Chinese porcelain "Clark porcelain"[3] exported in the 17 th century can be seen("Fig. 7").

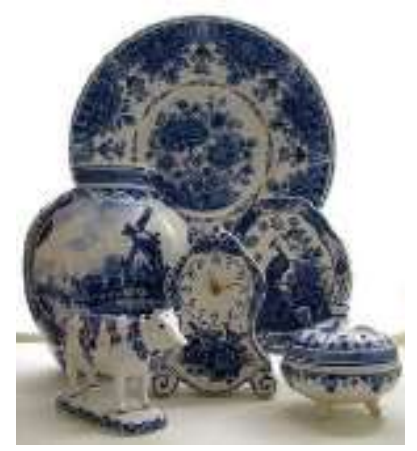

Fig. 6. Delft blue-and-white porcelain.

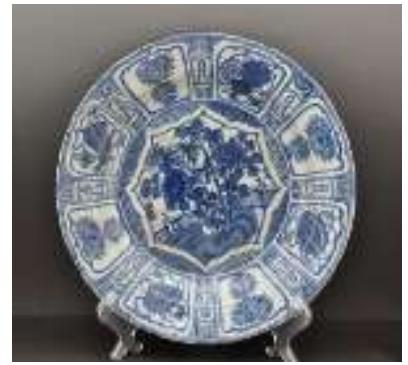

Fig. 7. Chinese porcelain exported in the 17 th century.

\section{B. Chinese Ceramics and International Market}

In 2015, China supplied ceramics to $70 \%$ of the world's population, but its revenues accounted for less than $20 \%$ of the total ceramics revenue in the world. A senior expert analyzed that if Guangdong's annual ceramic exports amount to 10 billion yuan, 5 billion of them will be used to buy foreign designs. Chaozhou City in Guangdong Province, is an important city for the export of daily-use ceramics in China and its export volume of daily-use ceramics accounts for 50\%$60 \%$ of the total export volume in China. In April 2004, the China Light Industry Confederation and the Ceramic Industry Association awarded Chaozhou the title "China porcelain capital"; the Ministry of Science and Technology of the People's Republic of China approved Chaozhou as the "National Industrial Base for Daily-use Ceramics". However, ceramics for daily use in Chaozhou are basically "made-tobrand" production for foreign ceramics, and they are "foundry" that relies on China's cheap labor to survive. The export porcelain of other porcelain producing areas in the country is also engaged in processing and production. The profitability of the ceramics factory depends on "three supplies and one 
subsidy" (that is, foreign supplied materials, samples, and supervision designers and the country's export subsidies). Since the 1990s, foreign companies in China have no longer supplied models (design drafts), but they have selected them in China and selected Chinese designers for their designs. However, exporting ceramics is still "branded", so, even these ceramic products are recognized by the world, they are not considered to be Chinese porcelain. Facing this situation, how China's modern ceramics industry should develop should be considered and studied by ceramic practitioners.

But in China, there is a ceramic company that is more successful. It is a Taiwanese business enterprise-Franz, which was founded in 2001 and has a production base in Jingdezhen. There are 92 direct-sale sites in department stores of the major cities in Chinese Mainland, 32 direct-sale sites in Taiwan, 2800 in the United States and Canada, 2100 in Europe, 200 in Asia, 900 in Australia and New Zealand, and more than 6000 sales sites in the world. The brand footprint is all over the world with the total sales volume more than 1 billion in one year. These data show that Franz is a world recognized brand. So, how does Franz do it? They three-dimensionalize the traditional Chinese flat decoration (see "Fig. 8"). This traditional daily-use ceramics that is considered to be inconvenient to use has won world recognition for its unique artistic style. The ceramic sculpture made for the 2008 Olympic Games by Franz showed the charm of Chinese contemporary ceramic art to the world with its precise dynamic and difficult molding technology ("Fig. 9").

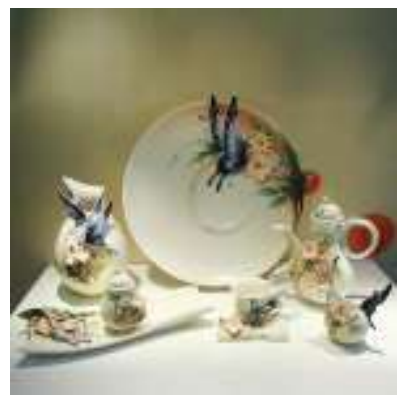

Fig. 8. Franz porcelain.

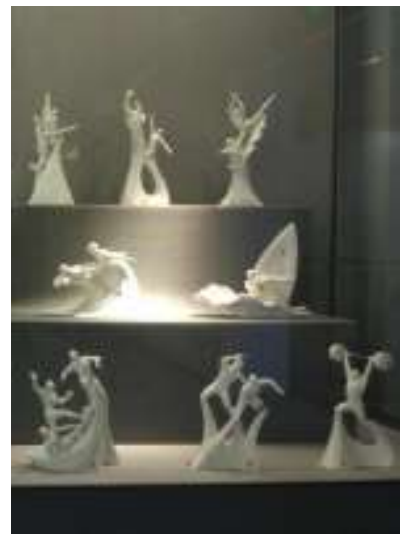

Fig. 9. The ceramic sculpture made for the 2008 Olympic Games by Franz.

If China has 10, 100 such enterprises as Franz, will the status of Chinese ceramics be changed? To keep up with the world's top ceramic brands, it is not enough to rely solely on traditional ceramic crafts and culture. Chinese ceramics must have its own brand, and ceramics majors trained in colleges and universities have a hard and long way to go.

\section{THE LEARNING AND EMPLOYMENT OF CERAMICS STUDENTS}

China's current economic and cultural background is very beneficial to the study and employment of ceramics majors. In the face of the status quo of Chinese ceramics in the international market, opportunities and challenges coexist, and the design talents of high-quality ceramics are also required to change. However, the largest employment and development space for ceramics majors still needs themselves to expand.

\section{A. Reading Ten Thousand Volumes of Books, Walking Ten Thousand of Miles [4]}

Students should have purposeful learning so that their talents will be outstanding and their own learning will be reflected in their lives. At the same time, they should increase their knowledge, combine theory with practice, and apply what they have learned. Most of the college students' learning is blind, and they just follow the teachers mechanically and lack the awareness of self-directed learning. In most colleges, professional teaching is staged (a professional class concentrates on 4-6 weeks of classes), and students may just begin to take another professional course when they are ready to go deeper. Lack of self-learning awareness makes the students' learning is often superficial, which led them to fear employment and choose to take part in the entrance exam for postgraduate schools following the fashion. Ceramics is a profession with strong craftsmanship, which demands ceramics majors to have a purpose in learning. Song Ying Xing said in "Tian Gong Kai Wu", "a total of seventy-two pieces of skill should be used to make a device."Since the Ming Dynasty, Chinese traditional ceramic production has already had a strict division of labor and collaboration. Even some porcelain artists have been repeating the same process for a lifetime, so that the craftsmanship is increasingly refined, so as to increase production efficiency and product quality. It is impossible for ceramics majors to master every step of ceramics, but it is necessary to be familiar with the craftsmanship of ceramics. The production technology of internationally renowned brand ceramics is not out of reach for our ceramics students. Their decoration techniques are required courses in college teaching. How to "learn to apply" is worth considering.

\section{B. Combination of Production, Teaching and Research}

The professional craftsmanship of ceramics is more suitable for the combination of production, teaching and research. There are some good experimental results in school teaching, but because they cannot be quantified, they are not known to the society. Students are in the learning stage. After a trial experiment, due to lack of technical support, failure to continue operations may make them abandon some better innovative designs. The Ministry of Education of the State adapts to the needs of the times and proposes the reform of university teaching. Many colleges and universities now offer 
"production-learning-research" teaching model featured by the combination of basic teaching and studio teaching with the purpose to allow students to learn the market as much as possible in the school learning stage, so that adapt society successfully after graduation. The main body of Jingdezhen ceramic creative industry is the students of Jingdezhen Ceramic Institute. They sell their creative ceramics at the weekend in creative market in the sculpture factory, attracting buyers from all over the country. In the process of ceramic production and sale, students will lay a solid foundation for professional knowledge and understand the market demand, so as to prepare for the future employment orientation or self employment.

\section{CONCLUSION}

It is no longer suitable for the present days that both ears are shut to what goes on outside the window and the whole mind is concentrated on the sage's books. A big market economy will guide students' learning and employment. Ceramics students should understand and analyze the current international and domestic situation of ceramics in order to be able to know themselves as well as the markets needs, find their own direction of development so that they can perform better study and employment and contribute to the ceramic industry in the motherland.

The current international and domestic situations are all very beneficial to the development of the Chinese ceramics industry, which will provide ceramics majors with more job opportunities and broader development space. However, how to grasp these opportunities requires that each student of ceramics major starts from their qualification, finds their own specialty and prepares well to meet opportunities and challenges.

\section{REFERENCES}

[1] Yongshan Yang, On Pottery Art[M].Harbin : Heilongjiang Art Publishing House, 2001， page10. 杨永善，说陶论艺 $[\mathrm{M}]$.哈尔滨： 黑龙江美术出版社，2001，第 10 页

[2] Blue-and-White Chinaware--In 1712, French missionary Yin Hongxu spread the raw materials of Chinese porcelain and its making method to Limoges, France.From then on, Europe began to produce genuine porcelain. Before that, Delft just fired blue and white pottery.[DB]. 青 花陶瓷器—-1712 年法国传教士殷弘绪, 将中国瓷器的原材料和 瓷器的制作方法传到法国利摩日, 从此之后, 欧洲才烧制出真正意 义上的瓷器, 在此之前代尔夫特烧制的是青花陶器。[DB]

[3] In 1602, the Dutch East India Co captured a Portuguese merchant ship "Clark" at sea.The ship was equipped with a large number of blue and white porcelain from China. Because of the unknown origin of porcelain, Europeans called it "Clark porcelain".[DB]. 公元 1602 年, 荷兰东印度公司在海上捕获一艘葡萄牙商船——克拉克号”, 船上 装有大量来自中国的青花瓷器, 因不明瓷器产地, 欧洲人把这种瓷 器命名为“克拉克瓷”。[DB]

[4] In ancient times, Wanjuan referred to the emperor's test paper.Reading aimed to go to Beijing to take the exam and make the title.Today,it is a metaphor for trying to read books and making oneself be equipped with extraordinarily talent and insight and at the same time,making sure that learn to use in life.Moreover, it means that increase knowledge and combine theory with reality.[DB]. 古代万卷是指皇帝的试卷。读书为 了进京赶考, 金榜题名。现比喻要努力读书, 让自己的才识过人并 让自己的所学, 能在生活中体现, 同时增长见识, 理论结合实际, 学以致用。[DB]
[5] Ming Dynasty • Yingxing Song 《Tian Gong Kai Wu》[M]Liao Xiong, Wei Xiong,The Ancient Books Integration of Chinese Ceramic.Shanghai:Shanghai Culture Press，2006, Page 209. 明 - 宋 应星《天工开物》 $[\mathrm{M}]$ 熊廖、熊微, 中国陶瓷古籍集成.上海: 上海 文化出版社，2006，第 209 页

[6] Gang Ning, The Design Revolution of China.. 宁钢, 中国的设计革命.

[7] Yanzu Li.Introduction to Arts and Crafts[M].Beijing: China Light Industry Press, 1999. 李砚祖.工艺美术概论 $[\mathrm{M}]$. 北京: 中国轻工业 出版社, 1999

[8] Jinhai Chen. The History of World Ceramic Art[M].Harbin : Heilongjiang Art Publishing House，1995. 陈进海.世界陶瓷艺术史 [M].哈尔滨: 黑龙江美术出版社, 1995

[9] Zhemin Ye.History of Chinese Ceramics[M].Beijing:SDX Joint Publishing Company, 2011 叶喆民.中国陶瓷史[M].北京: 生活・读 书・新知三联书店，2011 